\title{
ANALISIS TINGKAT KEMAMPUAN PEMAHAMAN KONSEP MAHASISWA PADA MATA KULIAH PEMROGRAMAN KOMPUTER
}

\author{
Ramdhan F. Suwarman \\ Universitas Suryakancana \\ ramdhan@unsur.ac.id
}

\begin{abstract}
ABSTRAK
Pemahaman konsep akan sebuah ilmu pengetahuan berperan penting, salah satunya untuk menghubungkan atau mengaitkan sebuah konsep yang satu dengan yang lainnya yang telah dipelajari. Oleh karenanya, kemampuan pemahaman konsep menjadi salah satu tujuan penting dalam pembelajaran. Pemahaman konsep memberikan pengertian bahwa materi yang diajarkan bukanlah hanya sebuah hafalan. Berdasarkan pentingnya peranan pemahaman akan sebuah konsep, dilakukanlah sebuah penelitian dengan tujuan untuk mengetahui dan menelaah tingkat kemampuan pemahaman konsep mahasiswa dan mengetahui kesalahan-keselahan mahasiswa dalam memahami mata kuliah pemrograman komputer. Penelitian dilakukan dengan menggunakan metode deskriptif kuantitatif dengan subjek penelitian mahasiswa peserta didik tingkat I mata kuliah Pemrograman Komputer Program Studi Pendidikan Matematika Universitas Suryakancana Tahun Akademik 2016-2017. Teknik Pengumpulan data dilakukan dengan menggunakan instrument tes. Hasil penelitian 1) Secara umum tingkat kemampuan pemahaman konsep mahasiswa pada mata kuliah pemprograman komputer adalah sedang dengan persentase kemampuan pemahaman konsep sebesar $68,724 \%$. 2) Kesalahan yang paling banyak dilakukan pada penyelesaian yang dilakukan mahasiswa adalah mengenai konsep $\mathrm{C}++$ dengan persentase sebesar 58,929\%.
\end{abstract}

Kata Kunci : Kemampuan Pemahaman Konsep, Pemporgraman Komputer, Deskriptif Kuantitatif. 


\section{PENDAHULUAN}

Menurut KBBI, definisi konsep adalah suatu ide atau gambaran dari objek melalui suatu proses yang digunakan untuk memahami hal-hal tertentu. Kemudian Nasution (2006) mengungkapkan bahwa konsep sangat penting bagi manusia, karena digunakan dalam komunikasi dengan orang lain, dalam berpikir, dalam belajar, membaca, dan lain-lain. Tanpa konsep, belajar akan sangat terhambat. Konsep juga termasuk dalam tujuan belajar, seperti yang diungkapkan oleh Sudirman (2011: 26-28). Sudirman mengungkapkan bahwa tujuan belajar pada umumnya ada tiga macam, yaitu:

a. Mendapatkan pengetahuan.

Hal ini ditandai dengan kemampuan berpikir, karena antara kemampuan berpikir dan pemilihan pengetahuan tidak dapat dipisahkan. Kemampuan berpikir tidak dapat dikembangkan tanpa adanya pengetahuan dan sebaliknya kemampuan berpikir akan memperkaya pengetahuan.

b. Penanaman konsep dan keterampilan.

Penanaman konsep memerlukan keterampilan, baik keterampilan jasmani maupun keterampilan rohani. Keterampilan jasmani adalah keterampilan yang dapat diamati sehingga akan menitikberatkan pada keterampilan penampilan atau gerak dari seseorang yang sedang belajar termasuk dalam hal ini adalah masalah teknik atau pengulangan. Sedangkan keterampilan rohani lebih rumit, karena lebih abstrak, menyangkut persoalan penghayatan, keterampilan berpikir serta kreativitas untuk menyelesaikan dan merumuskan suatu konsep.

c. Pembentukan sikap.

Pembentukan sikap mental dan perilaku anak didik tidak akan terlepas dari soal penanaman nilai-nilai, dengan dilandasi nilai, anak didik akan dapat menumbuhkan kesadaran dan kemampuan untuk mempraktikan segala sesuatu yang sudah dipelajarinya

Lebih jauh pemahaman akan sebuah konsep ilmu pengetahuan yang sedang dipelajari memiliki peranan yang sangat penting. Mahasiswa akan berkembang ke jenjang kognitif yang lebih tinggi jika ia memiliki pemahaman konsep yang baik. Jika pemahaman konsep dikuasai dengan baik maka mahasiswa akan mampu menghubungkan atau mengaitkan sebuah konsep yang satu dengan yang lainnya. Selain itu, konsep tersebut dapat juga digunakan untuk memecahkan permasalahan dari mulai yang sederhana hingga ke permasalahan yang lebih kompleks. Hal ini sesuai dengan pendapat Berns \& Erickson (2001). Berns \& Erickson (2001) berpendapat bahwa, dalam suatu domain belajar, 
pemahaman merupakan prasyarat mutlak untuk tingkatan kemampuan kognitif yang lebih tinggi, aplikasi, analisis, sintesis, dan evaluasi.

Pentingnya mahasiswa dalam memiliki kemampuan pemahaman matematis menjadi tolak ukur keberhasilan mahasiswa dalam prestasi. Pemahaman yang benar dan menyampaikan kepada orang lain melalui komunikasi lisan atau tulisan akan menambah kompetensi secara pengetahuan.

Oleh karena itu, peneliti ingin mengetahui dan menelaah sejauh mana kemampuan pemahaman mahasiswa melalui penelitian yang berjudul "Analisis Tingkat Kemampuan Pemahaman Konsep Mahasiswa pada Mata Kuliah Pemrograman Komputer”.

\section{METODE PENELITIAN}

Metode penelitian yang digunakan dalam penelitian ini adalah metode penelitian deskriptif kuantitatif. Hal ini bertujuan untuk mengetahui dan menelaah tentang kemampuan pemahaman matematis dan kesalahan mahasiswa dalam menyelesaikan soalsoal pada mata kuliah Pemprograman Komputer. Subjek penelitian yaitu mahasiswa peserta didik tingkat I mata kuliah Pemprograman Komputer Program Studi Pendidikan Matematika Universitas Suryakancana Tahun Akademik 2016-2017. Instrumen penelitian yang digunakan adalah instrumen tes berupa soal tertulis pada mata kuliah Pemrograman Komputer berkenaan dengan penulisan program dengan bahasa pemrograman $\mathrm{C}++$. Analisis data akan menggunakan deskriptif kuantitatif dalam menganalisis data hasil tes tertulis dari kemampuan pemahaman konsep mahasiswa.

\section{HASIL DAN PEMBAHASAN}

Hasil penelitian ini secara umum akan dibahas menjadi dua bagian, yaitu bagian tingkat kemampuan pemahaman konsep mahasiswa dan bagian kesalahan mahasiswa dalam melakukan penyelesaian tes yang diberikan. Berikut merupakan uraian hasil sekaligus pembahasannya.

\section{Tingkat Kemampuan Pemahaman Konsep Mahasiswa}

Data skor tingkat kemampuan pemahaman konsep mahasiswa bersumber dari hasil tes uraian pada mata kuliah Pemprograman Komputer dengan materi pengetahuan dasar tentang $\mathrm{C}++$ dan penulisan program sederhana $\mathrm{C}++$. Tes berbentuk uraian yang terdiri dari 5 soal untuk mengukur tingkat pemahaman konsep mahasiswa. Pada pengukuran tingkat pemahaman konsep mahasiswa pada penelitian ini merujuk pada kategori tingkat pemahaman konsep munurut Abraham yang diberi penilaian untuk mempermudah analisis. 
Kemudian data skor tingkat kemampuan pemahaman konsep akan diolah dengan menggunakan bantuan software IBM SPSS Statistics 20 dan Microsoft Excel 2016.

Berikut merupakan soal uraian yang digunakan dalam pengukuran tingkat tingkat kemampuan pemahaman konsep mahasiswa.

Tabel 1. Soal Pemahaman Konsep

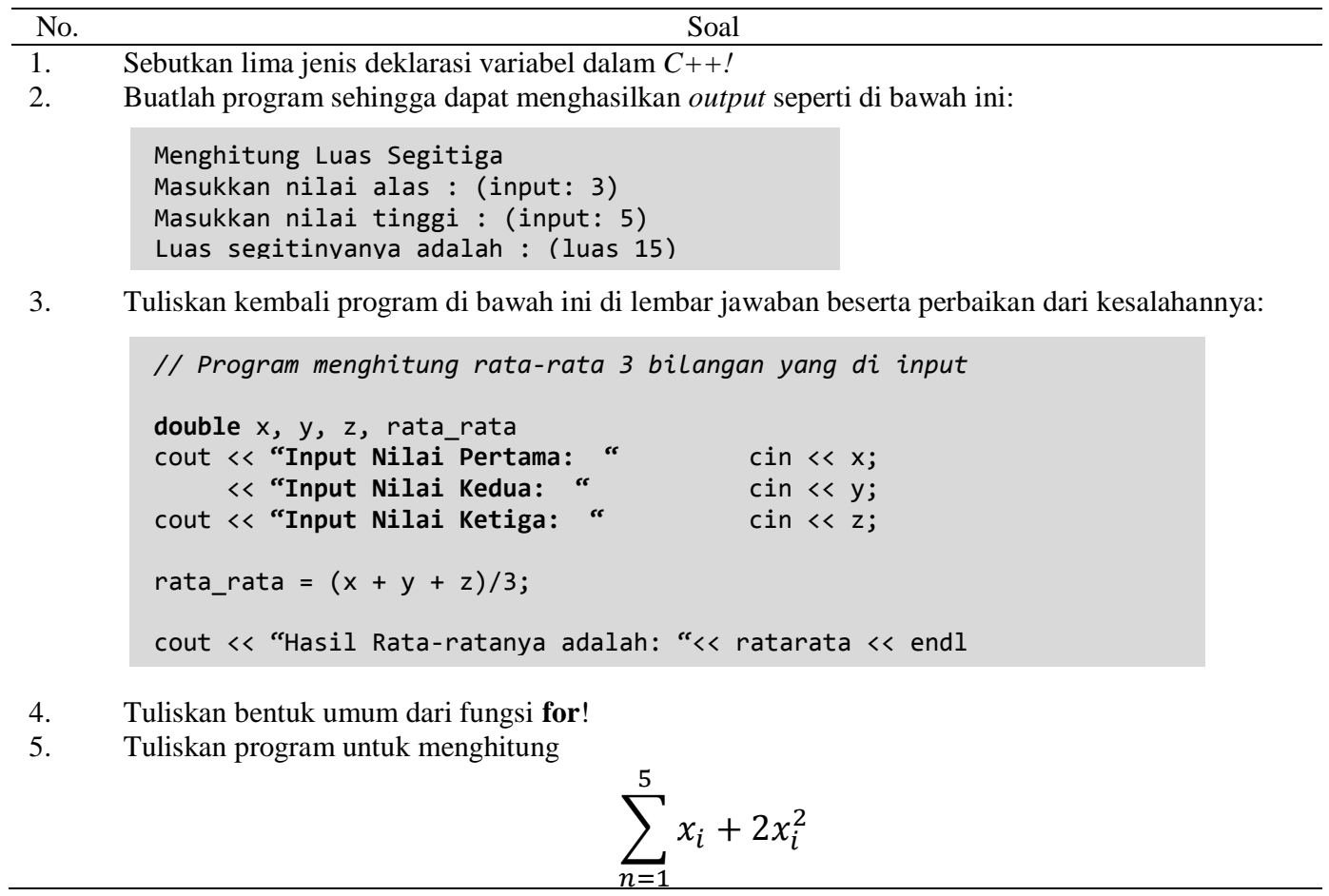

Berikut merupakan tabel tingkat pemahaman konsep munurut Abraham yang diberi penilaian:

Tabel 2. Kategori Tingkat Pemahaman Konsep Menurut Abraham.

\begin{tabular}{|c|c|c|c|}
\hline No. & Tingkat Pemahaman Konsep & Respon & Skor \\
\hline 1. & Tidak ada respon & Kosong / Saya tidak tahu / Saya tidak mengerti & 0 \\
\hline 2. & Tidak ada pemahaman konsep & Mengulangi pertanyaan yang tidak relevan atau tidak jelas & 1 \\
\hline 3. & Kesalahpahaman secara spesifik & Respon yang tidak logis atau informasi yang tidak benar & 2 \\
\hline 4. & $\begin{array}{l}\text { Pemahaman konsep parsial } \\
\text { dengan kesalahpahaman yang } \\
\text { spesifik }\end{array}$ & $\begin{array}{l}\text { Respon yang menunjukkan bahwa pemahaman konsep } \\
\text { juga menumbulkan pernyataan yang mengakibatkan } \\
\text { kesalahpahaman }\end{array}$ & 3 \\
\hline 5. & Pemahaman konsep parsial & $\begin{array}{l}\text { Respon yang mencakup setidaknya salah satu komponen } \\
\text { dari respon divalidasi, tetapi tidak semua komponen }\end{array}$ & 4 \\
\hline 6. & Pemahaman konsep yang baik & $\begin{array}{l}\text { Respon yang mencakup semua komponen respon } \\
\text { divalidasi }\end{array}$ & 5 \\
\hline
\end{tabular}

Berikut merupakan hasil umum pengolahan statistik deskriptif data skor tingkat kemampuan pemahaman konsep mahasiswa pada mata kuliah Pemprograman Komputer

Tabel 3. Statistik Deskriptif Tingkat Pemahaman Konsep.

\begin{tabular}{ccccccc}
\hline & $\begin{array}{c}\text { Jumlah } \\
\text { Data }\end{array}$ & $\begin{array}{c}\text { Skor } \\
\text { Ideal }\end{array}$ & $\begin{array}{c}\text { Skor } \\
\text { Minimum }\end{array}$ & $\begin{array}{c}\text { Skor } \\
\text { Maksimum }\end{array}$ & Rerata Skor & $\begin{array}{c}\text { Simpangan } \\
\text { Baku }\end{array}$ \\
\hline Skor & 22 & 25 & 12 & 22 & 17,181 & 3,002 \\
\hline
\end{tabular}


Berdasarkan Tabel 3 terlihat bahwa dari 22 data tingkat pemahaman konsep mahasiswa pada mata kuliah Pemprograman Komputer yang diolah, skor terendahnya adalah 12 dan skor tertingginya adalah 22 dari skor ideal 25. Kemudian rerata dari tingkat pemahaman konsep mahasiswa pada mata kuliah Pemprograman Komputer adalah 17,181 dengan simpangan baku sebesar 3,002.

Pada tabel berikutnya akan diuraikan secara lebih rinci tingkat pemahaman konsep mahasiswa pada mata kuliah Pemprograman Komputer berdasarkan soal yang diberikan.

Tabel 4. Statistik Deskriptif Tingkat Pemahaman Konsep.

\begin{tabular}{lcccccc}
\hline \multirow{2}{*}{ Skor } & \multicolumn{5}{c}{ Nomor Soal } & SKOR \\
\cline { 2 - 6 } & 1 & 2 & 3 & 4 & 5 & AKHIR \\
\hline Minimum & 2 & 3 & 0 & 2 & 0 & 12 \\
Maksimum & 5 & 5 & 5 & 5 & 5 & 22 \\
Rerata & 3,954 & 3,636 & 2,909 & 4,045 & 2,636 & 17,181 \\
Simpangan Baku & 0,898 & 0,581 & 1,445 & 0,843 & 1,329 & 3,002 \\
Modus & 4 & 4 & 3 & 4 & 3 & 18 \\
\hline
\end{tabular}

Berdasarkan Tabel 4 dapat dilihat bahwa untuk nomor 1 skor terendah tingkat pemahaman konsep mahasiswa adalah 2, skor tertingginya adalah 5, rerata adalah 3,954 dengan simpangan baku 0,898 dan modusnya adalah 4. Pada nomor 2 skor terendah tingkat pemahaman konsep mahasiswa adalah 3, skor tertingginya adalah 5, rerata adalah 3,363 dengan simpangan baku 0,581 dan modusnya adalah 4. Pada nomor 3 skor terendah tingkat pemahaman konsep mahasiswa adalah 0, skor tertingginya adalah 5, rerata adalah 2,909 dengan simpangan baku 1,445 dan modusnya adalah 3. Pada nomor 4 skor terendah tingkat pemahaman konsep mahasiswa adalah 2, skor tertingginya adalah 5, rerata adalah 4,045 dengan simpangan baku 0,843 dan modusnya adalah 4. Terakhir pada nomor 5 skor terendah tingkat pemahaman konsep mahasiswa adalah 0 , skor tertingginya adalah 5 , rerata adalah 2,636 dengan simpangan baku 1,329 dan modusnya adalah 3 .

Masih berdasarkan pada Tabel 5, pada nomor 3 dan 5 ada mahasiswa yang sama sekali tidak memberikan respon terhadap soal tersebut, kemudian untuk nomor lainnya mahasiswa masih memberikan respon meskipun tidak logis dan memberikan informasi yang salah. Tetapi secara umum pada setiap nomor dari soal yang diberikan ada mahasiswa yang mempunyai pemahaman konsep yang baik terhadap nomor tersebut. Hal ini terlihat dari skor maksimum 5 pada setiap nomornya.

Kemudian untuk skor rerata, soal nomor 5 menjadi soal yang paling kecil skor reratanya. Secara awal dapat disimpulkan bahwa soal nomor 5 menjadi soal dengan tingkat 
pemahaman konsep paling rendah diantara yang lain, disusul oleh soal nomor 3. Soal nomor 4 menjadi soal yang paling tinggi skor reratanya. Secara awal dapat disimpulkan bahwa soal nomor 4 menjadi soal dengan tingkat pemahaman konsep paling tinggi diantara yang lain, disusul oleh soal nomor 1.

Lebih lanjut masih berdasarkan hasil Tabel 5, soal nomor 3 menjadi soal dengan penyebaran skor paling tinggi, hal ini ditunjukkan oleh nilai simpangan baku sebesar 1,445 dari nomor ini yang merupakan skor simpangan baku tertinggi diantara yang lainnya. Kemudian nomor 3 menjadi soal dengan skor tingkap pemahaman konsep mahasiswa paling seragam diantara yang lainnya, hal ini ditunjukkan oleh nilai simpangan baku nomor ini yang terendah, yaitu 0,581 .

Terakhir berdasarkan skor modus dari Tabel 5, dapat disimpulkan bahwa pada nomor 1 secara umum tingkat pemahaman konsep mahasiswa berada pada tingkat "Pemahaman konsep parsial" yaitu mahasiswa mampu mengerjakan soal tersebut tetapi ada beberapa bagian dari soal yang tidak terjawab dengan benar. Secara umum pada nomor 2 dab 4 juga tingkat pemahaman konsep mahasiswa juga sudah berada pada tingkatan "Pemahaman konsep parsial". Kemudian untuk nomor 3 dan 5, pada umumnya tingkat pemahaman konsep mahasiswa untuk soal nomor ini berada pada tingkatan "Pemahaman konsep parsial dengan kesalahpahaman yang spesifik" yaitu mahasiswa belum terlalu memahami konsep yang harus dikuasai untuk mengerjakan soal nomor ini. Sehingga pada saat menjawab pertanyaan ini dengan pemahaman konsep yang tidak baik, mahasiswa menjadi salah dalam mengerjakan soal.

\section{Kesalahan Mahasiswa dalam Melakukan Penyelesaian Soal Tes}

Kesalahan mahasiswa dalam menyelesaikan soal yang diberikan pada mata kuliah Pemprograman Komputer biasanya merupakan hasil dari ketidaktelitian atau kurangnya pemahaman konsep pada materi yang telah diberikan.

Pada nomor 1 hampir seluruh mahasiswa dapat mengerjakan nomor ini. Dengan baik. Beberapa mahasiswa yang tidak dapat mengerjakan kebanyakan karena mereka lupa atau beberapa mahasiswa malah menjawab tidak sesuai dengan apa yang ditanyakan. Berikut merupakan contoh jawaban nomor yang disediakan pada Gambar 1 dan Gambar 2.

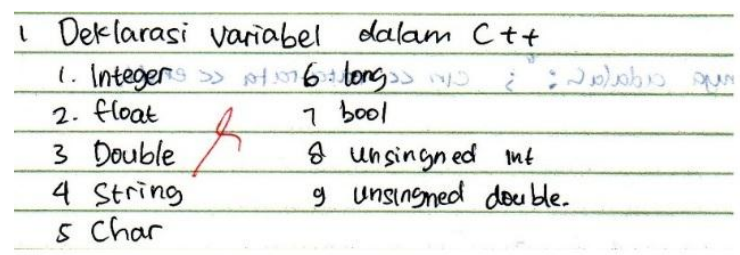


Gambar 1. Contoh Jawaban nomor 1

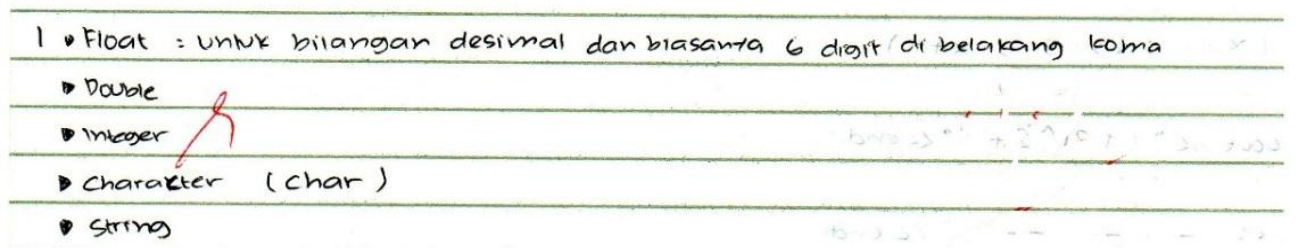

Gambar 2. Contoh Jawaban nomor 1

Pada nomor 2 beberapa mahasiswa melakukan kesalahan dalam pendeklarasian variabel, pada penulisan program $\mathrm{C}++$ yang tidak mengikutsertakan titik koma pada akhir setiap perintah, dan ada beberapa yang tidak mengetahui rumus untuk mencari luas segitiga. Berikut merupakan contoh jawaban nomor 2 yang disediakan pada Gambar 3 dan Gambar 4.

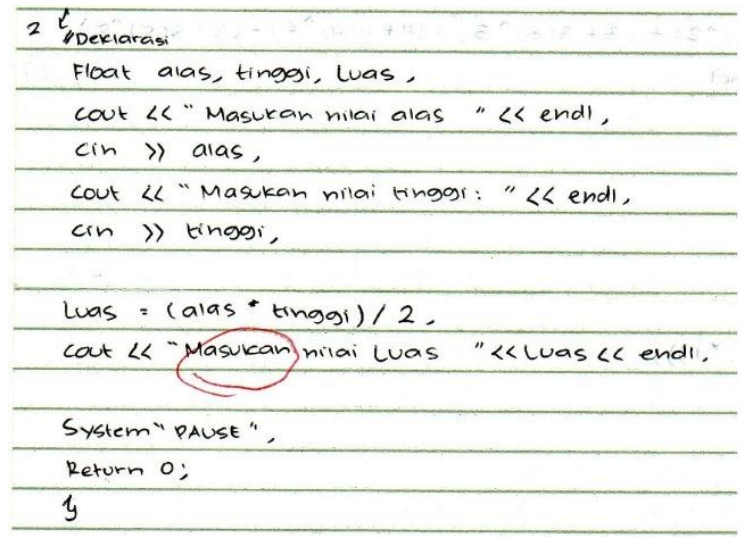

Gambar 3. Contoh Jawaban nomor 2

Pada nomor 3 banyak mahasiswa kurang teliti dalam memperhatikan kekurangan pengetikan pada setiap baris perintah yang harus dibenarkan dalam soal. Kekurangan tersebut memang terlihat seperti kekurangan kecil, misalkan hanya kekurangan tanda titik koma (;) atau kekurangan tanda kutip (") atau kesalahan pengetikan yang seharusnya lebih besar " $>>$ " dituliskan lebih kecil " $<<$ ". Bahkan kekurangan yang terlihat sangat kecil seperti ada spasi pada nama variabel. Tetapi semua kesalahan yang terlihat kecil ini berakibat pada program yang menjadi tidak dapat dijalankan. Berikut merupakan contoh jawaban mahasiswa untuk nomor 3. 


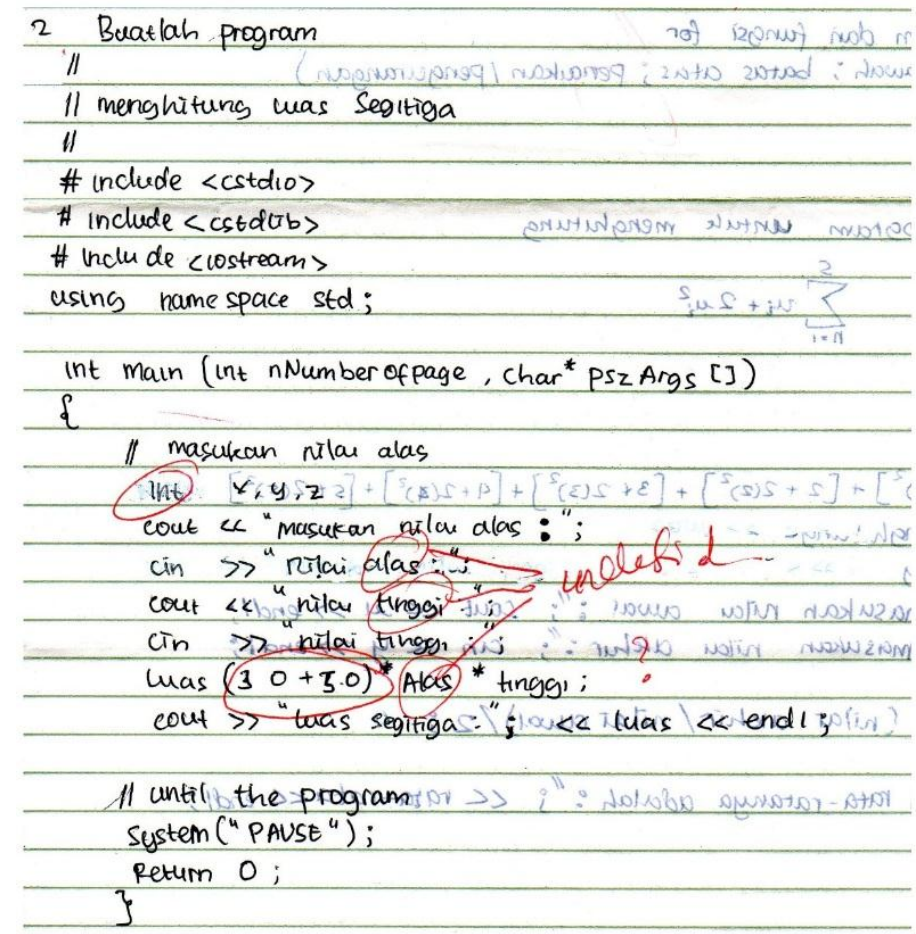

Gambar 4. Contoh Jawaban nomor 2

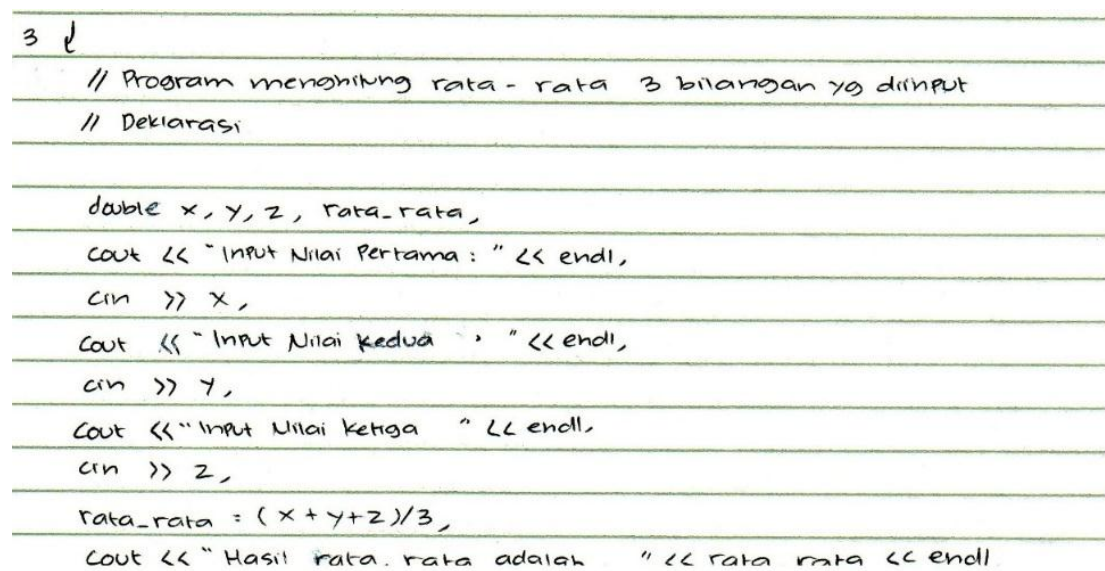

Gambar 5. Contoh Jawaban nomor 3

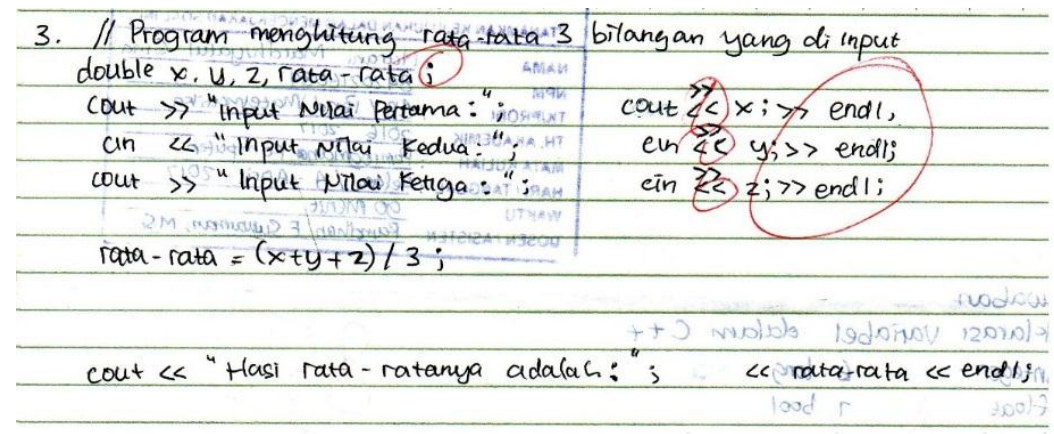

Gambar 6. Contoh Jawaban nomor 3

Pada nomor 4 secara umum mahasiswa sudah dapat mengerjakan soal ini dengan baik. Beberapa mahasiswa yang tidak dapat mengerjakan soal ini dengan baik dikarenakan 
mereka lupa bentuk umum dari fungsi "for". Berikut merupakan contoh jawaban mahasiswa untuk nomor 4.

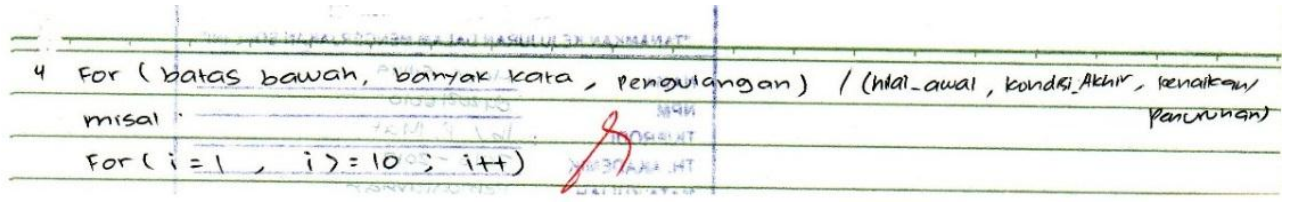

Gambar 7. Contoh Jawaban nomor 4

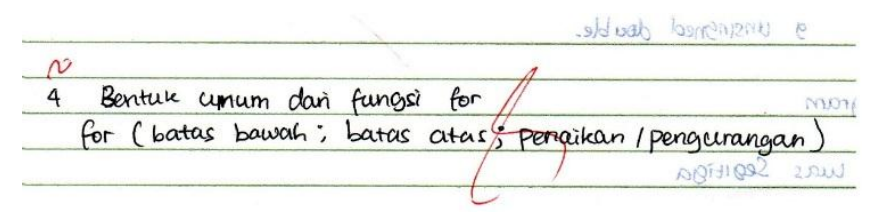

Gambar 8. Contoh Jawaban nomor 4

Pada nomor 5 yang merupakan soal dengan tingkat pemahaman konsep paling rendah diantara semua soal. Kesalahan yang terjadi pada nomor ini paling banyak tentang kesalahan konsep $\mathrm{C}++$ yang diketahui oleh mahasiswa, kemudian masalah dalam ketelitian mahasiswa dalam mengerjakan soal, ada juga kesalahan tentang konsep matematika oleh mahasiswa tentang operasi penjumlahan dan pangkat. Pada soal ini hanya ada beberapa mahasiswa saja yang dapat mengerjakan soal ini dengan baik. Berikut merupakan contoh jawaban mahasiswa untuk nomor 5.

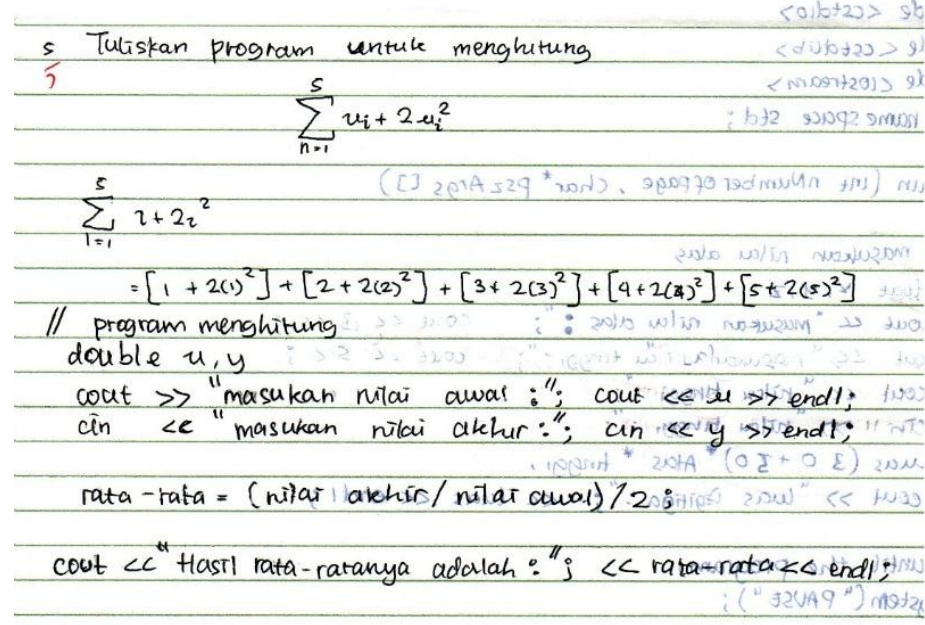

Gambar 9. Contoh Jawaban nomor 4

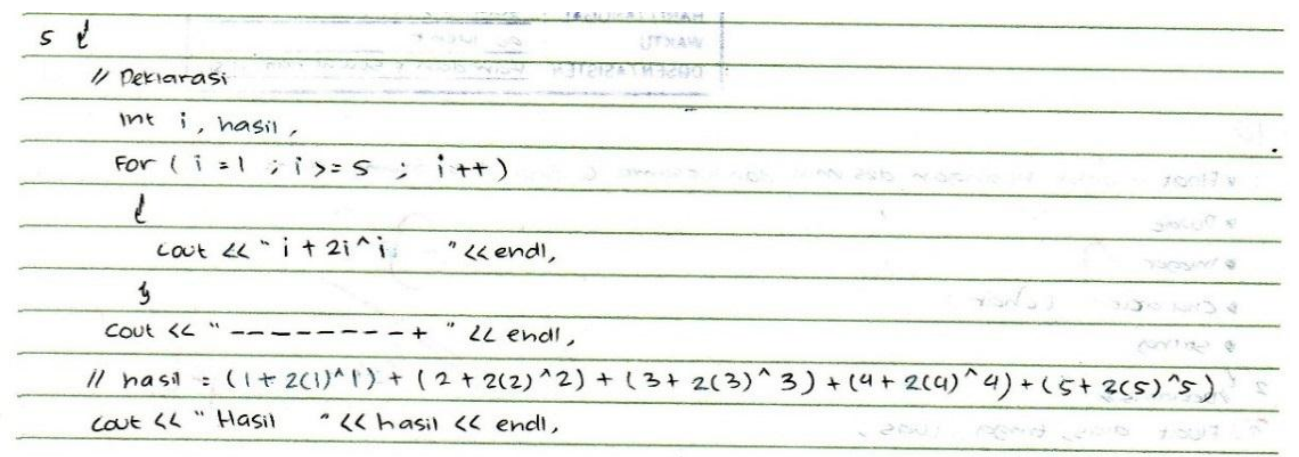


Gambar 10. Contoh Jawaban nomor 4

\begin{tabular}{l}
\hline$\quad$ Int $i$ i: \\
\hline double sum $=0 ;$ \\
for $(i=1 ; 1>0, i+t)$ \\
$\left\{\right.$ sum $=$ sum $+\left(i+2^{*}\left(i^{*} i\right)\right) i$ \\
\} cout $\ll$ sum $\ll$ end $1 ;$
\end{tabular}

Gambar 11. Contoh Jawaban nomor 4

Kesalahan yang dilakukan oleh mahasiswa dalam menyelesaikan soal dibedakan menjadi beberapa jenis untuk mempermudah proses analisis. Berikut merupakan tabel kesalahan yang sering terjadi pada penyelesaian soal pemprograman komputer

Tabel 5. Kesalahan Mahasiswa dalam Pengerjaan Soal

\begin{tabular}{cccc}
\hline No & Jenis Kesalahan & Jumlah & Persentase \\
\hline 1. & Konsep C++ & 33 & $58,929 \%$ \\
2. & Ketelitian & 14 & $25 \%$ \\
3. & Materi Matematika & 6 & $10,714 \%$ \\
4. & Lainnya & 3 & $5,357 \%$ \\
\hline
\end{tabular}

Berdasarkan Tabel 6 terlihat bahwa kesalahan terbanyak yang dilakukan oleh mahasiswa dalam pengerjaan soal adalah kesalahan konsep $\mathrm{C}++$ atau ketidaktahuan konsep $\mathrm{C}++$ yang seharusnya diketahui sebagai syarat untuk mengerjakan soal. Kesalahan konsep $\mathrm{C}++$ ini sangat banyak ditemui pada nomor 3 dan nomor 5. Berikut merupakan contoh jawaban salah mahasiswa.

\section{KESIMPULAN}

Berdasarkan hasil dan pembahasan pada bagian sebelumnya, dapat disimpulkan bahwa:

1. Secara rata-rata tingkat kemampuan pemahaman konsep mahasiswa pada mata kuliah Pemprograman Komputer adalah sedang dengan persentase kemampuan pemahaman konsep sebesar 68,724\%.

2. Kesalahan yang paling banyak terjadi pada penyelesaian yang dilakukan mahasiswa mengenai konsep $\mathrm{C}++$ dengan persentase sebesar 58,929\%.

Berdasarkan pada penelitian ini, maka diperlukan sebuah perbaikan pembelajaran untuk meningkatkan kemampuan pemahaman konsep mahasiswa pada mata kuliah pemprograman komputer. Sehingga diharapkan tingkat kemampuan pemahaman konsep mahasiswa pada mata kuliah tersebut dapat meningkat. Dikarenakan mata kuliah pemprograman komputer merupakan sebuah mata kuliah yang menekankan pada praktek, 
maka sebaiknya model pembelajaran yang akan digunakan untuk perbaikan pembelajaran dapat mempertimbangkan hal ini.

\section{REFERENSI}

Abraham, M.R., Gryzybowski, E.B., Renner, J.W., \& Marek, A.E. (1992). Understanding and Misunderstanding of Eighth Graders of Five Chemistry Concepts Found in Textbooks. Journal of Research in Science Teaching, 29, 105-120.

Anderson, L. W., \& Krathwohl, D. R. (Eds.) (2001). A taxonomy for learning, teaching, and assessing:A revision of Bloom's taxonomy of educational Objectives. New York: Longman.

Arikunto, S. (2009). Dasar-dasar Evaluasi Pendidikan. Jakarta: Bumi Aksara.

Firman, H. (2000). Penilaian Hasil Belajar dalam Pengajaran Kimia. Bandung: Jurusan Pendidikan Kimia FPMIPA UPI.

Kilpatrick, J., Swafford, J., \& Findell, D. (Eds). (2001). Adding It Up: Helping Children Learn Mathematics. Washington: National Academy Press.

Nasution, S. (2006). Azas-Azas Kurikulum. Universitas Michigan : Tarate.

Sugiyono. (2009). Metode Penelitian Pendidikan. Bandung: Alfabeta.

Suherman. dkk. (2003). Evaluasi Pembelajaran Matematika. Bandung: Jica.

Walle, J.A.V.D. (2008). Matematika Sekolah Dasar dan Menengah Pengembangan Pengajaran. Jakarta: Erlangga. 